\title{
WHOLE FARM NITROGEN BALANCE ON POULTRY FARMS IN CENTRAL BOSNIA REGION
}

\author{
Senada ČENGIĆ-DŽOMBA ${ }^{1 *}$, Velid ZILKIĆ ${ }^{1}$, Emir DŽOMBA ${ }^{1}$, \\ Dženan HADŽIĆ ${ }^{1}$
}

\begin{abstract}
At livestock farms most part of nitrogen arrives as purchased products (fertilizer, animal feed and purchased animals). Within the boundaries of the farm, nitrogen recycles between the livestock and crop components. Finally, nitrogen exit a livestock operation unit preferably as managed outputs (meat, crops and manure) sold off the farm. Difference between the inputs and the managed outputs represents an itrogen balance that can be an indicator of environmentally sustainable production. Nitrogen (im)balance consider only amount of the nutrient that cross the border of the farm. In ideal conditions the nitrogen input/output ratio should be 1:1. Some nitrogen exits the farm as losses to the environment (nitrates in groundwater, ammonia volatilized into the atmosphere, and nitrogen into groundwater and surface water).

A study was conducted on five small poultry farm in order to determine whole farm nitrogen balance as difference between total nitrogen inputs (one day chickens, litter, animal feed) and outputs (meat, dead animals and manure). Selected farms differ according to capacity (ranging from 5,000 to 40,000 birds), producers of poultry feed, type and length of manure storage as well as other sensible farming practice which could influence on nitrogen balance.

Collection of data on all farms is done using a questionnaire. Nitrogen content in all substrates (feed, manure, litter) was determinate by Kjeldahl procedure. The results of the whole farm nitrogen balance with the recommendations of its balancing in order to reduce the negative environmental implications are presented in the paper.
\end{abstract}

Keywords: whole farm nitrogen balance, broiler farms

\footnotetext{
${ }^{1}$ Faculty of Agricultural and Food Sciences, University of Sarajevo, Zmaja od Bosne 8, 71000 Sarajevo, Bosnia and Herzegovina

*Corresponding author: s.cengic-dzomba@ppf.unsa.ba
} 


\section{INTRODUCTION}

In the last few years, the poultry industry presented a significant increase in the animal production sector in Bosnia and Herzegovina. Awareness of the implications of poultry farming activities such as contamination of soil, surface and groundwater and air, have increased over the years. One of the major challenges in the modernization of poultry production is the need to reduce of the polluting effects on the environment and at the same time providing animal welfare demands and maintaining a profitable business.

Nutrients are transported along multiple pathways and in a variety of forms on a poultry operation. When it comes to environmental issues nitrogen plays an important role. At livestock farms most part of nitrogen arrives as purchased products (fertilizer, animal feed and purchased animals). Within the boundaries of the farm, nitrogen recycles between the livestock and crop components. Finally, nitrogen exit a livestock operation unit preferably as managed outputs (meat, crops and manure) sold off the farm. Difference between the inputs and the managed outputs represents a nitrogen balance that can be an indicator of environmentally sustainable production. Nitrogen (im)balance consider only amount of the nutrient that cross the border of the farm. In ideal conditions the nitrogen input/output ratio should be 1:1, but in the most farms practice nitrogen balance is far worse. Some nitrogen exits the farm as losses to the environment (nitrates in groundwater and surface water, ammonia volatilized into the atmosphere). Consequences include surface water and ground water pollution, eutrophication, increase of greenhouse effect, odor and acidification. Feed program and manure export practices are the most significant indicator of $\mathrm{N}$ balance variation. Purchased animal feeds are often the most significant source of the $\mathrm{N}$ inputs. The primary route of $\mathrm{N}$ excretion is fecal. Properly formulated ration that precisely meets the chicken's requirements for meat production and maintenance will minimize excessive $\mathrm{N}$ excretion.

In Bosnia and Herzegovina none study regarding whole poultry farm nitrogen balance conducted yet. Taking into account considerable number of poultry farm, knowledge of nitrogen flow at farms level could be basic step for improvement of $\mathrm{N}$ management at the farm.

\section{MATERIAL AND METHODS}

A study was conducted on five small poultry farms in central Bosnia region. The investigation was performed during the growing cycle that ran May - June 2015. Collection of data on all farms was done using a questionnaire. Questions referred to producers included: the hybrid and number of purchased and sold chickens and animal's products (meat), farm size, production of crops on the farm, the quantity of purchased feed (starter, grower, finisher), the quantity of purchased fertilizer, the amount of manure produced and sold, manure storage method. All data (information, questions) were related to the period of one production cycle (lasting from 35 to 38 days, depending of farm). 
Compound feeds of two commercial producers were used in the experiment. Chicken feeding was ad libitum. Feed samples were collected and analyzed to determine nitrogen, crude protein, crude fiber, ether extract and crude ash. Feed samples were taken randomly from several different points of the broiler sheds on each farm. Subsequently the samples are then mixed to a single blend to produce a collective sample, which again is divided into several representative laboratory samples for crude nutrient analysis. The feed samples were initially dried at $105^{\circ} \mathrm{C}$ for 3 hours. The weight loss of the sample is determined and the water fraction is calculated. Ashing the sample at $550^{\circ} \mathrm{C}$ for 4 hours all organic compounds are removed. Calculating the weight loss of the feed sample during ashing, mathematically determined the organic matter fraction. The nitrogen content of the feed was determinated using the Kjeldahl method on a Foss Kjeltec ${ }^{\mathrm{TM}} 2200$ analyzer. Multiplying the nitrogen content in \% obtained via Kjeldahl analysis with 6.25 gives an approximate crude protein (CP) content of the sample. Fats and lipids are extracted continuously with ether. After evaporation of the solvent the residue remaining was the ether extract (EE) fraction. Crude fiber (CF) was determined as the fraction, which is not soluble in a defined concentration of alkalis and acids.

Metabolisable energy (AME) content in compound feed was calculated according to Alvarenga et al. (2013):

$\mathrm{AME}_{\mathrm{n}}=4164.187+51.006 \mathrm{EE}-197.663 \mathrm{ASH}-35.689 \mathrm{CF}-20.593 \mathrm{NDF}$ (average literature data was used for neutral detergent fiber contents in diets).

The litter consisted of wheat straw were weighed than placed into broiler sheds and leveled to obtain an approximate depth of $10 \mathrm{~cm}$. Samples of straw were collected and analyzed for dry matter and nitrogen content before the start of production.

Litter sampling: At the end of the trial representative fresh poultry litter samples were collected from broiler sheds according to Best Management Practice procedure, before the litter was totally removed (Lavergne at al. 2011). Samples were dried in forced draft oven at $65^{\circ} \mathrm{C}$ for 24 hours, ground and stored in plastic bottles at room temperature till their analysis. Nitrogen and dry matter content in the litter were analyzed as described above.

The same hybrid (Cobb 500) was used in all five farms. One-day old chicks were received from a commercial hatchery. Chicks were weighed and determined their average weight at each farm. Literature data (Strakova et al. 2015, Von Bobrutzki et al. 2013) was used for calculating nitrogen content in whole bodies (including feathers) of one-day old chicken, dead birds end broiler chickens at the end of fattening period. Oneday old chicken nitrogen content was determined by multiplying average nitrogen content in whole bodies with average body weight. The content of nitrogen in the dead birds and broilers was determined by the same principle.

Whole-farm nitrogen balance was estimated as difference between total nitrogen inputs (one-day old chickens, straw, feed) and total nitrogen outputs (broilers, dead chickens 
and litter). This balance is interested only in the nitrogen that cross the border of the farm. It is not concerned with nitrogen recycled within the farm.

\section{RESULTS AND DISCUSSION}

Length of the production cycle was ranged from 35-38 days (38 days - Farm 1, 35 days - Farm 2, 3, 4 and 5).

Number of broiler chickens on farms involved in the study, ranged from 5,030 to 40,000. Initial number of chickens, number of living and dead birds, average body weight (oneday old, living and dead birds) is summarized in Table 1.

Table 1. Number of chickens and average body weight of broilers

\begin{tabular}{rrrrrrr}
\hline & \multicolumn{2}{c}{ Number of chickens } & \multicolumn{3}{c}{ Average body weight (BW), g } \\
& 1-day old & $\begin{array}{c}\text { Dead } \\
\text { birds }\end{array}$ & Final & 1-day old & $\begin{array}{l}\text { Dead } \\
\text { birds }\end{array}$ & Final \\
\hline \hline Farm 1 & 5030 & 75 & 4955 & 41 & 1075 & 2150 \\
\hline Farm 2 & 40000 & 1400 & 38600 & 39 & 1147 & 2255 \\
\hline Farm 3 & 9700 & 145 & 9555 & 41 & 1054 & 2150 \\
\hline Farm 4 & 9850 & 147 & 9703 & 42 & 1091 & 2225 \\
\hline Farm 5 & 20150 & 302 & 19848 & 42 & 1078 & 2198 \\
\hline
\end{tabular}

Chickens on the Farm 1 were fed with compound feed- $\mathrm{D}_{2}$, while on the other farms chickens were fed with a compound feed- $\mathrm{D}_{1}$. The content of crude nutrients in both compound feeds is presented in Table 2.

Table 2. Content of crude nutrients in compound feeds (as feed basis)

\begin{tabular}{lrrrrrr}
\hline \multirow{2}{*}{ Variable } & \multicolumn{2}{c}{ Compound feed $\left(\mathbf{D}_{1}\right)$} & \multicolumn{3}{c}{ Compound feed $\left(\mathbf{D}_{2}\right)$} \\
& Starter & Grower & Finisher & Starter & Grower & Finisher \\
\hline \hline Dry matter, \% & 91.13 & 91.18 & 90.35 & 90.37 & 90.33 & 90.04 \\
\hline Crude protein, \% & 21.43 & 20.66 & 15.56 & 20.27 & 19.01 & 18.26 \\
\hline Crude fat, \% & 4.93 & 6.32 & 7.78 & 4.81 & 7.36 & 8.93 \\
\hline Crude fiber, \% & 1.95 & 1.67 & 1.86 & 1.90 & 2.00 & 2.64 \\
\hline Ash, \% & 6.50 & 6.05 & 5.15 & 6.55 & 5.55 & 5.40 \\
\hline N, \% & 3.43 & 3.31 & 1.49 & 3.24 & 3.04 & 2.92 \\
\hline AME, kJ/kg & 12050.03 & 12724.45 & 13738.19 & 11977.61 & 13295.98 & 13650.04 \\
\hline AME, kcal/kg & 2880.02 & 3041.22 & 3283.50 & 2862.72 & 3177.82 & 3262,44 \\
\hline
\end{tabular}


Crude protein and dry matter content in wheat straw and litter is presented in Table 3. Data for nitrogen are expressed in dry matter bases. Litter nitrogen content in fresh litter ranged from $1.67 \%$ to $2.77 \%$. All nitrogen, in excess of the bird's requirement, is excreted. It basically means that reducing concentrations of nitrogen, in poultry litter/ manure can be achieved through feed supplements and feeding programs (Sutton and Lander, 2003). Using free amino acids or a diet with a lower protein content, nitrogen excretion through feces can be reduced by $10-27 \%$. The same source states that the use of enzymes (general) and phytases, highly digestible feedstuffs and phase feeding decreases nitrogen excretion by 5\%, 5\% and 10-33\% respectively. According to Powers and Angel (2008) applying 6-phase feeding program to broiler chickens, litter nitrogen content was decreased $16.6 \%$.

Table 3. Straw and litter characteristics

\begin{tabular}{lcccccccccc}
\hline \multirow{2}{*}{ Variable } & \multicolumn{2}{c}{ Farm 1 } & \multicolumn{2}{c}{ Farm 2 } & \multicolumn{2}{c}{ Farm 3 } & \multicolumn{2}{c}{ Farm 4 } & \multicolumn{2}{c}{ Farm 5 } \\
\cline { 2 - 11 } & straw & litter & straw & litter & straw & litter & straw & litter & Straw & Litter \\
\hline \hline $\begin{array}{l}\text { Dry matter, } \\
\text { \% }\end{array}$ & 92.32 & 41.64 & 94.57 & 53.76 & 93.94 & 58.22 & 90.61 & 66.59 & 93.82 & 60.95 \\
\hline N, \% of DM & 0.47 & 4.02 & 0.57 & 4.24 & 0.33 & 3.78 & 0.43 & 4.17 & 0.52 & 4,11 \\
\hline
\end{tabular}

Nitrogen inputs, nitrogen outputs and nitrogen input/output ratio at investigated farms are summarized in the Table 4. Nitrogen arrived on the investigated broiler farms in the form of purchased feed, imported chicken and imported straw. The greatest input of nitrogen to the all five farms, was purchased by feed $\left(99.24 \%\left(\mathrm{~F}_{1}\right), 98.80 \%\left(\mathrm{~F}_{2}\right), 98.71 \%\right.$ $\left(\mathrm{F}_{3}\right), 98.68 \%\left(\mathrm{~F}_{4}\right)$, and $98.67\left(\mathrm{~F}_{5}\right)$ of total nitrogen inputs.

The largest output of nitrogen from the farms was achieved through the sale of broiler chickens $\left(100 \%\left(\mathrm{~F}_{1}\right), 100 \%\left(\mathrm{~F}_{2}\right), 76.65 \%\left(\mathrm{~F}_{3}\right), 99.27 \%\left(\mathrm{~F}_{4}\right)\right.$, and $99.27\left(\mathrm{~F}_{5}\right)$ considering nitrogen which crossed the farms boundaries.

Table 4. Average whole-farm nitrogen balance per farm

\begin{tabular}{lrrrrr}
\hline \multicolumn{1}{c}{ Variable } & Farm 1 & Farm 2 & Farm 3 & Farm 4 & Farm 5 \\
\hline \hline N inputs, kg & \multicolumn{7}{c}{ F } \\
\hline Imported chicken & 5.28 & 39.94 & 10.18 & 10.59 & 21.66 \\
\hline Imported feed & & & & & \\
\hline Starter & 58.97 & 696.29 & 166.35 & 169.78 & 346.43 \\
\hline Grower & 290.62 & 2287.21 & 546.15 & 554.42 & 1145.26 \\
\hline Finisher & 394.20 & 759.90 & 159.43 & 161.66 & 330.78 \\
\hline Imported straw & 0.35 & 5.46 & 1.16 & 1.29 & 2.86 \\
\hline Total inputs & 749.43 & 3788.80 & 883.28 & 897.75 & 1846.99 \\
\hline
\end{tabular}




\begin{tabular}{lrrrrr}
\hline N outputs, kg & \multicolumn{7}{c}{. } & & & \\
\hline Broilers & 303.62 & 2480.73 & 585.48 & 615.29 & 1243.34 \\
\hline Manure (litter) & 0 & 0 & 174.07 & 0 & 0 \\
\hline Dead birds & 0 & 0 & 4.28 & 4.49 & 9.12 \\
\hline Total outputs & 303.62 & 2480.73 & 763.83 & 619.78 & 1252.45 \\
\hline Inputs-outputs & 445.81 & 1308.07 & 119.45 & 227.97 & 594.54 \\
\hline Inputs/outputs : 1 & 2.45 & 1.53 & 1.16 & 1.45 & 1.47 \\
\hline Output/input, \% & 40.51 & 65.47 & 63.31 & 69.04 & 67.81 \\
\hline
\end{tabular}

Inputs/outputs $\mathrm{N}$ ratio ranged from 1.15:1 $\left(\mathrm{F}_{3}\right)$ to $2.45: 1\left(\mathrm{~F}_{1}\right)$. The best nitrogen balance was found on a farm $\left(\mathrm{F}_{3}\right)$, then on farms $\left(\mathrm{F}_{4}\right),\left(\mathrm{F}_{5}\right),\left(\mathrm{F}_{2}\right),\left(\mathrm{F}_{1}\right)$ and amounted 1.16; 1.45; $1.47 ; 1.53$ and 2.45 respectively. The reason for this balance was satisfactory system for disposal of dead birds on $\left(\mathrm{F}_{3}, \mathrm{~F}_{4}\right.$ and $\left.\mathrm{F}_{5}\right)$ farms. An unsatisfactory system of dead birds removal, during the production cycle, was applied at the other farms. On those farms dead birds were buried near broiler houses, which is unacceptable from an environmental standpoint. Also, removing the manure from the farm immediately after the end of fattening was applied on the farm $\left(\mathrm{F}_{3}\right)$. Although the production practice at all farms was cleaning out broiler houses after every batch, only one farmer $\left(\mathrm{F}_{3}\right)$ have been sold their manure after batch, what is positively reflected on the balance of nitrogen. On the other farms, manure was stored up to one year in inadequate locations. According to investigations conducted in Louisiana nitrogen input/output ratio amounted 2.7:1 if the manure stays on the farm. According to Chastain et al. (2003) nitrogen losses from litter storage ranged from $17 \%$ (covered pile) to $30 \%$ (uncovered pile).

The results indicate that birds given Diet 1 had a similar (and better) nitrogen balance ratio (Table 4) and feed conversion ratio-FCR (Table 5) compared to the birds consuming Diet 2.

Table 5. Basic production characteristic at investigated farms

\begin{tabular}{ccccc}
\hline & $\begin{array}{c}\text { Live weight } \\
\text { gain, g/bird }\end{array}$ & $\begin{array}{c}\text { Total feed } \\
\text { intake, kg }\end{array}$ & $\begin{array}{c}\text { Feed intake, } \\
\text { g/bird }\end{array}$ & $\begin{array}{c}\text { Feed conversion } \\
\text { ratio, FCR }\end{array}$ \\
\hline \hline Farm 1 & 2109 & 24880 & 5020 & 2,38 \\
\hline Farm 2 & 2216 & 140400 & 3637 & 1,64 \\
\hline Farm 3 & 2109 & 32050 & 3354 & 1,59 \\
\hline Farm 4 & 2183 & 32550 & 3355 & 1,53 \\
\hline Farm 5 & 2156 & 66900 & 3371 & 1,56 \\
\hline
\end{tabular}

Poorer live weight gain (LWG) and higher FCR at the Farm 1 might be explained by unbalanced protein/energy ratio in grower and finisher diet. According to Domaćinović et al. (2015) the optimal protein/energy ratio in starter diet should be 1: $570-590 \mathrm{~kJ}$, while the preferred ratio in the grower diets is 1:630-650 kJ. Protein/energy ratio in 
grower and finisher diets by which were fed the broilers on the Farm 1 was 1:699 (grower) and 1:747 (finisher).

Consequently, feed intake decreased as the dietary content of energy increased and the protein intake decreased as well. As a result, live weight decreased and FCR was impaired. On the other hand starter diets had balanced protein/energy ratio, but protein and energy content were slightly above the Cobb and NRC (1994) recommendations. A direct consequence of shortage of protein and energy content in diets is increasing feed intake. Taking into account that the largest input of nitrogen to the farms is achieved through the broiler diets, an unfavorable balance (2.45) could have been expected.

Crude protein content in starter and grower diet used at farms $F_{2}, F_{3}, F_{4}$ and $F_{5}$, was in line with the Cobb recommendations, while in the finisher diets was below recommendations. Protein/energy ratio in starter diet was balanced. Energy content in starter and grower diets was nearly optimal, only in the finisher diets was slightly higher. Considering this, as well as the shorter fattening period, a better nitrogen balance and FCR in these farms is understandable. A feed efficiency is much better in the first weeks of broiler production and then declines with increased target market weight. Since the feed efficiency declines as broilers get older, this fact should be taken into consideration when comparing different age flocks.

\section{CONCLUSIONS}

Farm nitrogen balances are a useful indicator for nitrogen losses and the potential for improving $\mathrm{N}$ management. The investigation has shown that poultry feed has a crucial impact on the nitrogen balance on the farm. Improving the whole-farm nitrogen balance can be achieved by applying nutrition strategies focused on reducing nitrogen excretion. Broiler chickens generally digest about 85 to $90 \%$ of the dry matter of the feed. One of the most important tasks is to formulate diets which improve the efficiency of nutrient retention by animals and decrease their excretion in urine and feces. To achieve this it is necessary to harmonize the amount of protein in the diet with the real broiler requirements, or apply phase broilers feeding. Also, the amount of energy in diets should be in line with the recommendation. Diets must be high enough in energy, provided from fat and carbohydrates, otherwise, dietary protein will be used by the bird to meet a substantial part of its energy requirement. It should emphasize a balanced protein/energy ratio in diets. For instance the use of free amino acids and highly digestible feedstuffs is a very efficient way to improve dietary protein quality and reduce nitrogen excretion.

Microclimatic conditions in the broiler house should be managed in a way that minimize litter moisture and improve litter quality. Wet litter is the primary cause of ammonia emissions. Therefore, the proper litter management is also important factor for optimal whole farm nitrogen balance. 


\section{REFERENCES}

Alvarenga, R.R., P.B. Rodrigues, M.G. Zangeronimo, L. Makiyama, E.C. Oliveira, R.T.F. Freitas, R.R. Lima, and V.M.P, Bernardino. 2013. Validation of Prediction Equations to Estimate the Energy Values of Feedstuffs for Broilers: Performance and Carcass Yield, Asian-Australas Journal of Animal Science, 26(10): 14741483.

Chastain, J.P., J.J. Camberato, and P. Skewes. 2003. Poultry Manure Production and Nutrient Content. Clemson University Extension, South Carolina Confined Animal Manure Managers Certification Program: Poultry, Clemson, SC.

Cobb 500. Broiler Performance and Nutrition Supplement. www.cobb-vantress.com Accessed: November 2015.

Domaćinović, M., Z. Antunović, E. Džomba, A. Opačak, M. Baban, and S. Mužic. 2015. Specijalna hranidba domaćih životinja. Hranidba peradi. p.p. 442. ISBN 978-9537871-44-4.

Lavergne,T., R.E. Sheffield, B.D. LeBlanc, and K.E. Nix. 2011. Poultry Environmental Best Management Practices (BMPs). Louisiana State University Agricultural Center. Pub. 2806 (online only) Rev. 04/11.

National Research Council (NRC). 1994. Nutrient Requirements of Poultry: Ninth Revised Edition, Subcommittee on Poultry Nutrition, National Academy Press Washington, D.C. 1994.

Powers, W. and R. Angel. 2008. A Review of the Capacity for Nutritional Strategies to Address Enviromental Challenges in Production. Poultry Science 87: 19291938.doi:10.3382/ps.2008-00090

Strakova, E., P. Suchy, P. Navratil, T. Karel, and I. Herzig. 2015. Comparison of the content of crude protein and amino acids in the whole bodies of cocks and hens of Ross 308 and Cobb 500 hybrids at the end of fattening. Czech J. Anim. Sci., 60.(2):67-74.

Sutton, A. and Ch. H. Lander. 2003. Effects of Diet and Feeding Managemen on Nutrient Content of Manure Nutrient Management Technical Note No. 1. USDA. Natural resource conseration service.

Von Bobrutzki, K., C. Ammon, W. Berg, and M. Fiedler. 2013. Quantification of nitrogen balance components in a commercial broiler barn. Czech J. Anim. Sci., 58, 2013 (12) $566-577$. 